\title{
NEPHRON NUMBER IN THE OFFSPRING OF RATS FED A LOW PROTEIN DIET DURING PREGNANCY
}

\author{
MONIKA A ZIMANYI, JOHN F BERTRAM AND JANE M BLACK \\ Department of Anatomy and Cell Biology, Monash University, Victoria 3800, Australia \\ e-mail: monika.zimanyi@med.monash.edu.au \\ (Accepted July 26, 2000)
}

\begin{abstract}
In experimental studies it has been shown that intrauterine growth retardation and reduced kidney growth during development are associated with significant decreases in nephron endowment. However, the results of previous studies may be inaccurate as nephron counts were obtained using a maceration technique, which can lead to breakdown of glomeruli, and other potentially biased techniques. In the present study, the total number of glomeruli (and thereby nephrons) in the offspring of rats fed a low (9\%) or normal (20\%) protein diet during pregnancy were estimated using a physical disector/fractionator technique. The offspring of rats fed a low protein diet had a significantly lower birth weight than rats fed a normal protein diet, their kidneys were smaller and they contained $30 \%$ fewer nephrons $(20,386 \pm 4,818$ in the low protein diet vs. $28,731 \pm 3,290$ in the control rats). Our results, obtained using an unbiased stereological technique confirm previous findings that administration of a low protein diet during pregnancy results in reduced nephron endowment in the offspring.
\end{abstract}

Keywords: glomeruli, low birth weight, nephron, protein restriction, rat, stereology.

\section{INTRODUCTION}

Hypertension is a major risk factor for cardiovascular diseases such as ischaemic heart disease, coronary heart disease, atherosclerosis, stroke and endstage renal disease. Epidemiological studies have shown that low birth weight is associated with an increased incidence of hypertension in adult life (Barker et al., 1990) suggesting a link between fetal nutrition, development and adult cardiovascular disease. It has been suggested that even brief periods of undernutrition may result in permanent alterations in growth that may be translated into pathology in later life (Barker, 1995).

Experimental studies have shown that administration of a low protein diet (9\% protein) during pregnancy in rats results in smaller offspring than in those fed a normal (18\%) protein diet (Langley-Evans and Nwagwu, 1998). It has been postulated that reductions in nephron number in low birth weight infants may be the cause of the development of hypertension later in life. Brenner et al. (1988) hypothesised that reduced glomerular filtration surface area in the kidney, due to a decrease in the number of glomeruli and/or a decrease in surface area per glomerulus would lead to renal sodium retention and a subsequent increase in mean arterial blood pressure.
In support of this hypothesis, low birth weight resulting from intrauterine growth retardation has been shown to be associated with deficits in the number of glomeruli in human infants (Hinchliffe et $a l ., 1992)$ and in offspring of rats fed a low protein diet during pregnancy (Merlet-Benichou et al., 1994; Langley-Evans et al., 1999). While the number of glomeruli in humans was estimated using an unbiased stereological technique (Hinchliffe et al., 1992), the number of glomeruli in rats was estimated using either an acid maceration technique (Merlet-Benichou et al., 1994), or a biased counting method (LangleyEvans et al., 1999). Hence it is possible that the results of these earlier studies may be inaccurate. The aim of the present study was to determine the total number of glomeruli (and thereby nephrons) in the offspring of rats fed a low or normal protein diet during pregnancy using an unbiased physical disector/fractionator technique.

\section{MATERIALS AND METHODS}

\section{ANIMALS}

Female Wistar-Kyoto rats were fed, ad libitum, a low $(9 \%)$ or normal $(20 \%)$ protein diet for 2 weeks before mating to habituate them to their diets, during 
pregnancy and for 2 weeks after the birth of the pups to ensure that nephrogenesis was complete in the offspring. Nephrogenesis is known to be complete in rats by postnatal day 8 (Larsson et al., 1980). After giving birth, litters were reduced to eight pups by preferentially culling abnormally small or large pups of the litter and/or females. Remaining pups were housed with the mother until the weaning age of 4 weeks, at which time female littermates were excluded from further experimentation and male rats were perfusion fixed.

\section{PERFUSION FIXATION}

Rats were given a $0.1 \mathrm{ml}$ intraperitoneal injection of both heparin sodium (25000 units in $5 \mathrm{ml}$ ) and papaverine hydrochloride $(120 \mathrm{mg}$ in $10 \mathrm{ml}) 5 \mathrm{~min}$ prior to anaesthetising. Rats were anaesthetised using sodium pentobarbitone (Nembutal) at $0.6 \mathrm{mg} / 60 \mathrm{~g}$ body weight. The abdominal aorta was exposed via an incision in the abdominal wall and a catheter inserted into the aortic bifurcation. Physiological saline $(\mathrm{pH}$ 7.4) was used to clear the vasculature after severing the vena cava. Perfusion with $2.5 \%$ glutaraldehyde in $0.1 \mathrm{M}$ phosphate buffer at a pressure of $100 \mathrm{mmHg}$ was performed. The left kidneys were excised, decapsulated and stored in the buffered glutaraldehyde.

\section{Histological preparation}

The left kidneys were sliced into $1 \mathrm{~mm}$ thick slices using a razor blade cutting device. All kidney slices from the left kidney were placed in cassettes, dehydrated through a series of graded alcohols, infiltrated and embedded in glycolmethacrylate Technovit 7100 (Heraeus Kulzer, Germany) resin. Blocks were then exhaustively sectioned at $20 \mu \mathrm{m}$ using a Leica RM2165 supercut microtome. Every $10^{\text {th }}$ (sampled section) and $11^{\text {th }}$ (look up section) was collected, with the first section between 1 and 10 chosen at random. Sections were mounted on glass slides, placed in a $60^{\circ} \mathrm{C}$ oven for $48 \mathrm{~h}$ and stained with haematoxylin and eosin.

\section{DETERMINATION OF KIDNEY VOLUMES}

Every $10^{\text {th }}$ kidney section was viewed on a Fuji Minicopy Microfiche screen at a magnification of $24.25 \times$. A $2 \mathrm{~cm} \times 2 \mathrm{~cm}$ orthogonal grid was placed on the viewing screen. The number of grid points overlying all kidney tissue (complete and incomplete sections) was counted $\left(\mathrm{P}_{\mathrm{s}}\right)$ as well as the number of grid points on complete kidney sections $\left(\mathrm{P}_{\mathrm{f}}\right)$. The volume of the kidney was estimated using the Cavalieri principle, using the formula:

$$
\mathrm{V}_{\text {kid }}=10 \times \mathrm{t} \times \mathrm{a}(\mathrm{p}) \text { microfiche } \times \mathrm{P}_{\mathrm{s}},
$$

where 10 was the inverse fraction of the kidney slices sampled, $t$ was mean section thickness, and $a(p)$ was the area associated with each grid point on the microfiche screen (Bertram et al., 1992; 1995).

\section{Estimation of total number of glomeruli using the physical disector/fractionator combination}

Complete sections, that is, sections in which both the circumference and centre of the tissue were intact were used. Two modified microscopes with projection arms were used to count glomeruli with physical disectors. The first section of the pair, the sampled section $\left(10^{\text {th }}\right)$ was placed on the stage of the right hand microscope, which was fitted with a motorised stage. The corresponding look-up section $\left(11^{\text {th }}\right)$ was placed on the stage of the second microscope, which had a rotating stage to aid in the alignment of the sections. The motorised stage was connected to a computer that controlled the stepping procedure needed for systematic uniform random sampling of tissue. The two corresponding fields of view were projected onto two identical unbiased counting grids on the table top, side by side in a darkened room.

To determine the fraction of complete sample sections used for glomerular counting, points on kidney tissue in sampled fields were counted $\left(\mathrm{P}_{\text {kid }}\right)$. $\mathrm{P}_{\mathrm{kid}}$ is therefore a fraction of $\mathrm{P}_{\mathrm{f}}$, which is itself a fraction of $\mathrm{P}_{\mathrm{s}}$.

The glomerular profiles sampled by an unbiased counting frame of the sampled section, which were not present in the look-up section were counted $\left(\mathrm{Q}^{-}\right)$, and to double the efficiency, glomerular profiles sampled by an unbiased counting frame of the lookup section, which were not present in the sampled section were also counted (Sterio, 1984). Total glomerular number was estimated using:

$$
\mathrm{N}_{\text {glom,kid }}=10 \times\left(\mathrm{P}_{\mathrm{s}} / \mathrm{P}_{\mathrm{f}}\right) \times\left[1 /\left(2 \mathrm{f}_{\mathrm{a}}\right)\right] \times \mathrm{Q}^{-},
$$

where 10 is the inverse of the section sampling fraction, $\mathrm{P}_{\mathrm{s}} / \mathrm{P}_{\mathrm{f}}$ and $1 /\left(2 \mathrm{f}_{\mathrm{a}}\right)$ is the fraction of the total section area used to count glomeruli and $\mathrm{Q}^{-}$is the actual number of glomeruli counted (Bertram et al., 1992; 1995). $f_{a}$ was obtained using:

$\mathrm{f}_{\mathrm{a}}=\left[\mathrm{P}_{\text {kid }} \times \mathrm{a}(\mathrm{p})\right.$ disector $] /\left[\mathrm{P}_{\mathrm{f}} \times \mathrm{a}(\mathrm{p})\right.$ microfiche $]$,

where $\mathrm{P}_{\text {kid }}$ was the number of grid points falling of kidney tissue, $P_{f}$ was the number of grid points overlying complete sections and $\mathrm{a}(\mathrm{p})$ was the area associated with each grid point corrected for magnification. $2 f_{a}$ refers to the fact that disectors were counted in both directions, thereby doubling $f_{a}$. 


\section{STATISTICS}

All data are expressed as means \pm SD (standard deviation). Analyses were carried out using a oneway analysis of variance using Graphpad Prism (version 3). Where significant differences were detected, Tukeys post hoc test was applied. Statistical significance was accepted at a level of $p<0.05$.

\section{RESULTS}

Body weights of female breeder rats were not affected by altering protein consumption during pregnancy. Administration of a low protein diet during pregnancy did not significantly affect litter size.

Offspring of rats exposed to a low protein diet during pregnancy had significantly lower birth weights $(p<0.001)$ and kidney volumes $(p<0.05)$ than the offspring of rats exposed to a normal protein diet (Table 1). Total nephron number was approximately $30 \%$ lower $(\mathrm{p}<0.05)$ in the kidneys of the offspring of rats fed a low protein diet than in the kidneys of offspring of rats fed a normal protein diet (Table 1).

\section{DISCUSSION}

The major findings of this study are that the offspring of rats fed a low protein diet during pregnancy had lower birth weight, and smaller kidneys than the offspring of rats fed a normal protein diet and their kidneys contained fewer nephrons.

In the present study maternal undernutrition throughout pregnancy was used to induce intrauterine growth retardation. Feeding a $9 \%$ protein diet to pregnant rats had no observable adverse effects on weight gain during pregnancy or reproductive success of the female breeders. These findings are consistent with the work of others (Woodall et al., 1996; Desai et al., 1996). Birth weights of offspring of rats fed a low protein diet during pregnancy were significantly lower than those of control rats, and is in agreement with the findings of others (Desai et al., 1996; Woodall et al., 1996; Tonkiss et al., 1998).

Using an unbiased stereological technique we have found that the consumption of a low protein diet during pregnancy significantly reduces nephron endowment in the offspring. These findings are in agreement with those of Merlet-Benichou et al. (1994), who reported that the kidneys of offspring of rats fed a low (5\%) protein diet had 28,902 \pm 686 nephrons compared to $35,014 \pm 853$ in offspring of rats fed a normal $(22 \%)$ protein diet. The estimates of glomerular number obtained by Merlet-Benichou et al., (1994) are higher than the present estimates. This may relate to the use of the acid maceration technique in their study, which involves digestion of kidney tissue and can lead to glomerular fragmentation.

Similarly, Langley-Evans et al. (1999) observed reduced nephron numbers in 4-week-old offspring of rats fed a low protein diet during pregnancy. Their estimates of glomerular number were $15,154 \pm 818$ nephrons in rats exposed to a normal (18\%) protein diet and 13,074 \pm 409 nephrons in rats exposed to a low (9\%) protein diet. The estimates of glomerular number of Langley-Evans et al. (1999) differ from many other estimates of nephron numbers in rats obtained by either stereological or acid maceration techniques. For example, Skov et al. (1994) found $28,500 \pm 1,200$ nephrons in the kidneys of WistarKyoto rats, and Bertram et al. (1992) reported $31,764 \pm 3,667$ nephrons in the kidneys of SpragueDawley rats. The method employed by Langley-Evans et al. (1999) clearly leads to a gross underestimation of glomerular number in the rat kidney.

In conclusion, we have found that administration of a low protein diet to rats during pregnancy leads to offspring with lower birth weight and smaller kidneys, and the kidneys contain fewer nephrons. Using an unbiased stereological technique we have confirmed previous reports that exposure to a low protein diet in utero leads to reduced nephron endowment.

Table 1. Birth Weight, Kidney Volume and Glomerular Number in Offspring of Rats Fed a Low and Normal Protein Diet During Pregnancy.

\begin{tabular}{lcc}
\hline & Low Protein Diet $(\mathrm{n}=6)$ & Normal Protein Diet $(\mathrm{n}=5)$ \\
\hline Birth Weight $(\mathrm{g})$ & $3.31 \pm 0.20^{* *}$ & $3.97 \pm 0.25$ \\
Kidney volume $\left(\mathrm{mm}^{3}\right)$ & $155.34 \pm 25.78^{*}$ & $283.75 \pm 73.31$ \\
Number of glomeruli & $20,386 \pm 4,818^{*}$ & $28,731 \pm 3,290$
\end{tabular}

$(* * \mathrm{p}<0.001 ; * \mathrm{p}<0.05)$ 
A preliminary report of some of the data was presented at the $X^{\text {th }}$ International Congress for Stereology, Melbourne, Australia, 1-4 November 1999.

\section{ACKNOWLEDGEMENTS}

This study was supported by a grant from the Australian National Health and Medical Research Council (NH\&MRC).

\section{REFERENCES}

Barker DJP (1990). Fetal and placental size and risk of hypertension in adult life. Br Med J 301:259-62.

Barker DJP (1995). Fetal origins of coronary heart disease. Br Med J 311:171-4.

Bertram JF (1995). Analyzing renal glomeruli with the new stereology. Int Rev Cytol 161:111-72.

Bertram JF, Soosaipillai MC, Ricardo SD, Ryan GB (1992). Total numbers of glomeruli and individual glomerular cell types in the normal rat kidney. Cell Tissue Res 270:37-45

Brenner BM, Garcia DL, Anderson S (1988). Glomeruli and blood pressure - Less of one, more the other? Am J Hypertens 1:335-47.

Desai M, Crowther NJ, Lucas A, Hales CN (1996). Organselective growth in the offspring of protein-restricted mothers. Brit J Nutr 76:591-603.

Hinchliffe SA, Lynch MRJ, Sargent PH, Howard CV, Van Velzen D (1992). The effect of intrauterine growth retardation on the development of renal nephrons. Br J
Obstet Gynaecol 99:296-301.

Langley-Evans SC, Nwagwu M (1998). Impaired growth and increased glucocorticoid-sensitive enzyme activities in tissues of rat fetuses exposed to maternal low protein diets. Life Sci 63:605-15.

Langley-Evans SC, Welham SJM, Jackson AA (1999). Fetal exposure to a maternal low protein diet impairs nephrogenesis and promoted hypertension in the rat. Life Sci 64:965-74.

Larsson R, Aperia A, Wilton P (1980). Effect of normal development on compensatory renal growth. Kidney Int 18:29-35.

Merlet-Benichou C, Gilbert T, Muffat-Joly M, LelievrePegorier M, Leroy B (1994). Intrauterine growth retardation leads to a permanent nephron deficit in the rat. Pediatr Nephrol 8:175-80.

Skov K, Nyengaard JR, Korsgaard N, Mulvany MJ (1994). Number and size of renal glomeruli in spontaneously hypertensive rats. J Hypertens 12:1373-6.

Sterio DC (1984). The unbiased estimation of number and sizes of arbitrary particles using the disector. J Microsc 134:127-36.

Tonkiss J, Trzcinska M, Galler JRT, Ruiz-Oparo N, Herrera VLM (1998). Prenatal malnutrition-induced changes in blood pressure-dissociation of stress and non-stress responses using radiotelemetry. Hypertens 32:108-14.

Woodall SM, Johnston BM, Breier H, Gluckman PD (1996). Chronic maternal undernutrition in the rat leads to delayed postnatal growth and elevated blood pressure of offspring. Pediat Res 40:438-43. 